\title{
Can psychedelics be the treatment for the crisis in psychopharmacology?
}

Genís Ona $^{1,2}$

José Carlos Bouso ${ }^{1}$

${ }^{1}$ ICEERS Foundation (International Center for Ethnobotanical Research, Education and Services), Barcelona, Spain

${ }^{2}$ Universitat Rovira i Virgili, Department of Anthropology, Philosophy and Social Work, Tarragona, Spain.

E-mail addresses: genisona@iceers.org// jcbouso@iceers.org

*Corresponding author: José Carlos Bouso

- $\quad$ E-mail address: jcbouso@iceers.org

- $\quad$ Full postal address: ICEERS Foundation. Calle Sepúlveda n ${ }^{\circ} 65$, Bajos $2^{\circ}$, Barcelona (postal code: 08015).

\begin{abstract}
The current crisis in psychopharmacology has a long history and needs to be addressed with innovative and effective strategies. Here we discuss some of the roots of this crisis and suggest that the therapeutic use of psychedelic drugs represents a promising and integrative treatment with enduring effects for mental health problems.
\end{abstract}

Keywords: Mental health, psychedelics, psychopharmacology, psychiatry, innovative

The authors declare no competing financial interest.

Acknowledgments: None 
Can psychedelics be the treatment for the crisis in psychopharmacology?

\section{Introduction}

For the past few years, we have been witnessing a crisis in the field of psychopharmacology. Generally, it takes a decade and up to a billion dollars in investment to get a drug on the market. Furthermore, the majority of new drugs are ruled out during the pre-clinical phase. Less than $20 \%$ of the selected drugs make it to Phase-III evaluation involving humans. Drug development has never been an easy task. However, in psychiatric drug research there are additional difficulties that have led to the current crisis.

Tracing the history of psychiatric drug research helps map out the crisis that this field is currently facing. Before 1950s, only barbiturates and chloral hydrate were available for the treatment of psychiatric symptoms. These drugs were ineffective and were associated with serious adverse effects. But in the 1950s and early 1960s, several novel drug classes were discovered for the treatment of psychiatric disorders, a process that has been referred to as the "psychopharmacology revolution". ${ }^{1}$ With more effective and safer drugs, the field of psychiatry developed new patterns of assistance, reducing the number of patients admitted to institutions and therefore improving their quality of life. The biomedical model that was developed based on these observations has been extensively criticized. ${ }^{2,3}$ Some authors suggest that this model has produced the current conceptual crisis in psychiatry, ${ }^{4}$ generating potentially erroneous situations such as excessive confidence in oversimplified treatments, including those based only on pharmacotherapy (or, worse, polypharmacy) $)^{5}$.

Additionally, early psychopharmacological research faced various limitations, as Horrobin $^{6}$ explained in detail in an interesting text published in the Oxford Textbook of Medicine. He found that the five most successful therapeutic strategies to be used in the modern history of psychiatry were drugs developed (or rediscovered) during the 1950s or after: lithium, monoamine oxidase inhibitors, phenothiazines, tricyclic antidepressants, and benzodiazepines. The first three drugs listed were discovered by serendipity, and the final two were discovered through discredited screening techniques. Horrobin $^{6}$ subsequently concluded that these discoveries were not dependent on the regular medical research strategy.

These and other issues mentioned by Horrobin more than 30 years ago were recently highlighted anew by Insel and Sahakian, ${ }^{7}$ as well as in statements from various eminent health professionals, suggesting that the state of psychopharmacology research has not changed significantly in the past few decades. Both DePaulo, ${ }^{8}$ past chairman of the Department of Psychiatry and Behavioral Sciences at Johns Hopkins University, and Insel, ${ }^{9}$ former Director of the National Institute of Mental Health, have noted that 
modern psychopharmacological treatments are not more beneficial than past ones, despite their higher cost. In addition, Fibiger, ${ }^{10}$ former Vice President of Neuroscience at Eli Lilly, has stated straightforwardly that psychopharmacology is in crisis. This is evidenced by the reality that not one innovative drug has reached the psychiatric market in more than 30 years. This is partly due to widely-used yet questionable practices, such as making minimal modifications to drugs that are already available and commercializing them as "new" products (known as "me-too" drugs). For this reason, our present psychiatric drugs are little better than those that were available in the 1950s. ${ }^{9,11}$ One of the constraints hampering drug development may be the fact that the molecular targets of psychiatric drugs have not changed in the last 50 years, and even today we do not understand some of the mechanisms through which they work. ${ }^{12}$ This lack of knowledge about the exact mechanisms is worsened by an inability to validate the fundamental hypotheses about mental disorders. ${ }^{13}$

Evidently, we are lacking innovative approaches, and we need to use creative and efficient strategies in order to improve our understanding of psychiatric drugs and their effects. Focusing on certain molecular targets exclusively would be a limited approach, at least if it is not combined with psychotherapy. Furthermore, chronic treatment with these medications might be more harmful than beneficial. ${ }^{14,15}$ This is evident in the case of benzodiazepines, one of the most widely-used classes of drugs. ${ }^{16}$ Based on the above, it can be deduced that psychiatry is facing serious challenges, since psychopharmacology (which offers the best therapeutic strategies in this regard) is in crisis. Furthermore, this crisis is having an inescapable negative impact on public health. ${ }^{17}$

\section{Examples of the crisis}

We can think of depression and post-traumatic stress disorder (PTSD) as examples of conditions impacted by this crisis. Many meta-analyses suggest that drug-placebo differences are minimal in antidepressant treatment ${ }^{18-20}$ and that antidepressant drug treatments are useful only in cases of severe depression. ${ }^{21,22}$ In addition to their questionable efficacy, antidepressants can produce serious adverse reactions. ${ }^{23-25}$

The pharmacological treatment of PTSD is also in crisis, as the PTSD Psychopharmacology Working Group of the US Department of Veteran Affairs recently stated. $^{26}$ The prevalence of lifetime PTSD among the general population is approximately $6.8 \%{ }^{27}$ Despite this high prevalence, there are only two medications approved for the treatment of PTSD, sertraline and paroxetine, which only produce reduction in symptom severity rather than remission of $\mathrm{PTSD}^{26}$ The fact that antidepressants cannot produce remission of PTSD symptomatology may be because PTSD is not an aberrant response of the brain, but a normal response to an aberrant situation. This is why patients with PTSD tend to respond better to psychosocial treatments than to pharmacotherapy. ${ }^{28}$ Since 2001 , no new medication has been 
approved for the treatment of PTSD, despite the significant need. This scenario has pushed clinicians to adopt poly-pharmacological approaches for the vast majority of their patients, using off-label medications regarding which there is little empirical guidance concerning risks or benefits. ${ }^{26}$ Among these medications, we find benzodiazepines, which are not only ineffective but are also associated with negative psychotherapy outcomes, aggression, depression, and illicit substance use in PTSD patients. $^{29}$

While the situation is especially troubling in terms of depression and PTSD, the psychiatric drugs crisis is widespread. In 2011, an editorial published in the British Journal of Clinical Pharmacology claimed that in one year they only published five papers concerning CNS drugs, none of which involved novel drugs. ${ }^{30}$ They also expressed concerns over the cessation of psychiatric drug research as conducted by GSK, Astra Zeneca, and other major pharmaceutical companies. Andrew Witty, CEO at GlaxoSmithKline, alleged that it is not possible to test the efficacy of psychiatric drugs even after large-scale trials. ${ }^{31}$

\section{Psychedelic drugs as treatment for the crisis}

Recently, the Royal Society convened an International Scientific Seminar in order to discover innovative solutions to the psychiatric drugs crisis. One of the conclusions reached was that we need a paradigm shift in terms of how we view and approach mental health research. ${ }^{31}$ Similar conclusions were drawn in a report published by $\mathrm{Nesta}^{32}$ that focused on the biomedical bubble in which life sciences are immersed. Some researchers pointed out recently that psychedelic-assisted psychotherapy might offer a partial solution for overcoming this crisis. ${ }^{33,34}$ Treatment targets for disorders like depression and PTSD have been too focused on symptom relief instead of recovery. ${ }^{35,36}$ Psychiatric disorders are complex, so instead of an oversimplified neurobiological approach, a more integrative treatment is required that combines pharmacological tools with psychosocial interventions. ${ }^{31}$ Psychedelic-assisted psychotherapy could satisfy this need, offering pharmacological action along with enhanced psychotherapeutic interventions. ${ }^{33}$

Psychedelic drugs activate different G-protein-coupled receptors (GPCRs), but several studies identified 5-HT2A as the main receptor responsible for the behavioral effects of psychedelic drugs. ${ }^{36}$ Although serotonin acting via 5-HT2 receptors produces pro-inflammatory actions, ${ }^{37}$ psychedelic drugs such as lysergic acid diethylamide (LSD) or 2,5-Dimethoxy-4-iodoamphetamine (DOI) primarily show potent anti-inflammatory effects. ${ }^{38}$ The activation of $2 \mathrm{~A}$ receptors has also been associated with neurogenesis ${ }^{39,40}$ and neuronal plasticity. ${ }^{41}$ Remarkably, N,N-Dimethyltryptamine (DMT) and other psychedelics have been termed "psychoplastogens" due to their promotion of rapid structural and functional neural plasticity. ${ }^{42}$ This emphasis on the modulation of neural circuits through fast-acting psychoplastogens instead of rectifying chemical imbalances 
using long-term treatments suggests a considerable paradigm shift. DMT and LSD also activate trace amine-associated receptors (TAARs), ${ }^{43}$ a GPCR subfamily the agonism of which is associated with antipsychotic, antidepressant, and antiaddictive properties. ${ }^{43}$ For a complete review of the pharmacological mechanisms of psychedelic drugs, see Kyzar et al. $2017 .^{36}$

Regarding the enhancement of psychotherapeutic interventions, psychedelic drugs could trigger meaningful personal concerns, ${ }^{44,45}$ facilitate introspective insights ${ }^{33}$ and enhance the relationship between the therapist and the patient, ${ }^{46}$ among other effects. Additionally, there are some idiosyncrasies of this kind of assisted psychotherapy that deserve mention. First, the drug (generally psilocybin, LSD or ayahuasca) is used on one or a few occasions during psychotherapy sessions in order to overcome obstacles and to catalyse the therapeutic experience. ${ }^{33}$ Second, it is assumed that the psychedelic experience itself, and not only the pharmacological effect, will offer therapeutic effects. ${ }^{47}$.

In the last 15 years, interest in the therapeutic potential of psychedelic drugs has increased. Several clinical trials have been published and show promising results for the treatment of depression, ${ }^{48-51}$ anxiety in cancer patients, ${ }^{55-55}$ addictions, ${ }^{56}$ social anxiety in autism, ${ }^{57}$ and PTSD. ${ }^{58-62}$ See Table 1. Actually, beyond the mere demonstration of efficacy, it has been suggested that some of these treatments could represent the first evidence-based and pharmacologically-mediated cure in psychiatry. ${ }^{63}$ For a review of the clinical use of psychedelic drugs, see dos Santos et al. $2016 .{ }^{64}$ In addition to these substances, it is also remarkable the therapeutic potential that ibogaine has shown for the treatment of addictions, mostly in the treatment of opioid dependence, ${ }^{65}$ becoming a potential solution for the opioid crisis occurring in many countries. The first RCT in which ibogaine will be administered in patients with alcoholism will begin in 2019 (ClinicalTrials.gov Identifier: NCT03380728). In contrast with clinical trials, the notion that psychedelic drugs are harmful is challenged when we examine real-world situations. Psychedelic drug use is associated with a lower rate of mental health problems $^{66}$ and with reduced psychological distress and suicidality ${ }^{67}$ in population studies. 


\begin{tabular}{|c|c|c|c|c|}
\hline $\mathrm{RCT}$ & Core topic & $\mathrm{N}^{\mathrm{o}}$ of patients & Main findings & Limitations \\
\hline $\begin{array}{l}\text { Grob et al. } \\
\quad 2011\end{array}$ & $\begin{array}{l}\text { Psilocybin for } \\
\text { the treatment of } \\
\text { anxiety } \\
\text { associated with } \\
\text { life-threatening } \\
\text { disease }\end{array}$ & 12 & $\begin{array}{l}\text { Significant reductions } \\
\text { in anxiety } \\
\text { after } 1 \text { and } 3 \\
\text { months post-treatment }\end{array}$ & No control group \\
\hline $\begin{array}{l}\text { Mithoefer et al. } \\
\qquad 2011\end{array}$ & $\begin{array}{l}\text { MDMA for the } \\
\text { treatment of } \\
\text { PTSD }\end{array}$ & 20 & $\begin{array}{l}\text { MDMA-assisted } \\
\text { psychotherapy can be } \\
\text { safely administered to } \\
\text { PTSD patients, and it } \\
\text { may be useful in } \\
\text { patients refractory to } \\
\text { other treatments }\end{array}$ & $\begin{array}{l}\text { Potential selection bias } \\
\text { Per-protocol analysis }\end{array}$ \\
\hline $\begin{array}{c}\text { Oehen et al. } \\
2013\end{array}$ & $\begin{array}{l}\text { MDMA for the } \\
\text { treatment of } \\
\text { PTSD }\end{array}$ & 12 & $\begin{array}{l}\text { MDMA-assisted } \\
\text { psychotherapy can be } \\
\text { safely administered in } \\
\text { a clinical setting }\end{array}$ & $\begin{array}{l}\text { Unbalanced groups } \\
\text { Low adherence to } \\
\text { MDMA-psychotherapy } \\
\text { protocol }\end{array}$ \\
\hline $\begin{array}{c}\text { Gasser et al. } \\
2014\end{array}$ & $\begin{array}{l}\text { LSD for the } \\
\text { treatment of } \\
\text { anxiety } \\
\text { associated with } \\
\text { life-threatening } \\
\text { disease }\end{array}$ & 12 & $\begin{array}{l}\text { When administered } \\
\text { safely in a medically } \\
\text { supervised } \\
\text { psychotherapeutic } \\
\text { setting, LSD can } \\
\text { reduce anxiety }\end{array}$ & Potential selection bias \\
\hline $\begin{array}{l}\text { Griffiths et al. } \\
2016\end{array}$ & $\begin{array}{l}\text { Psilocybin for } \\
\text { the treatment of } \\
\text { anxiety } \\
\text { associated with } \\
\text { life-threatening } \\
\text { disease }\end{array}$ & 51 & $\begin{array}{l}\text { Immediate and } \\
\text { long-term decrease of } \\
\text { anxiety after } \\
\text { administration of } \\
\text { high-dose psilocybin }\end{array}$ & $\begin{array}{l}\text { Measures not validated } \\
\text { Low external validity }\end{array}$ \\
\hline $\begin{array}{l}\text { Ross et al. } \\
\quad 2016\end{array}$ & $\begin{array}{l}\text { Psilocybin for } \\
\text { the treatment of } \\
\text { anxiety } \\
\text { associated with } \\
\text { life-threatening } \\
\text { disease }\end{array}$ & 29 & $\begin{array}{l}\text { Immediate and } \\
\text { sustained } \\
\text { improvement of } \\
\text { anxiety and depression }\end{array}$ & Potential selection bias \\
\hline $\begin{array}{l}\text { Danforth et al. } \\
2018\end{array}$ & $\begin{array}{l}\text { MDMA for the } \\
\text { treatment of } \\
\text { social fear and } \\
\text { avoidance in } \\
\text { autistic adults }\end{array}$ & 12 & $\begin{array}{l}\text { MDMA- assisted } \\
\text { psychotherapy can be } \\
\text { safely administered } \\
\text { and produce rapid and } \\
\text { durable improvement } \\
\text { in social anxiety } \\
\text { symptoms in autistic } \\
\text { adults }\end{array}$ & $\begin{array}{l}\text { AEs reported } \\
\text { Inclusion criteria not } \\
\text { comprehensive }\end{array}$ \\
\hline $\begin{array}{l}\text { Palhano-Fontes } \\
\text { et al. } 2018\end{array}$ & $\begin{array}{l}\text { Ayahuasca for } \\
\text { the treatment of } \\
\text { depression }\end{array}$ & 29 & $\begin{array}{l}\text { Ayahuasca is safe and } \\
\text { dosed within an } \\
\text { appropriate setting, } \\
\text { has therapeutic value } \\
\text { to treat depression }\end{array}$ & No follow-up \\
\hline $\begin{array}{c}\text { Ot'alora et al. } \\
2018\end{array}$ & $\begin{array}{l}\text { MDMA for the } \\
\text { treatment of } \\
\text { PTSD }\end{array}$ & 28 & $\begin{array}{l}\text { PTSD symptoms } \\
\text { remained lower than } \\
\text { baseline at } 12-\text { month } \\
\text { follow-up with } 76 \% \text { of } \\
\text { the patients not } \\
\text { meeting PTSD criteria }\end{array}$ & $\begin{array}{c}\text { Limited } \\
\text { generalizability of } \\
\text { findings. } \\
\text { No control group to } \\
\text { compare at follow-ups }\end{array}$ \\
\hline
\end{tabular}

Table 1. Modern Randomized Clinical Trials (RCT) involving the administration of psychedelic substances. $\mathrm{RCT}=$ Randomized Clinical Trial; MDMA=3,4-Methyl 
enedioxymethamphetamine; PTSD= Posttraumatic Stress Disorder; LSD= Lysergic acid diethylamide; $\mathrm{AEs}=$ Adverse Events.

The Journal of Psychopharmacology, Psychopharmacology, and Neuropharmacology dedicated entire issues to psychedelic drugs, in December of 2016, February of 2018, and November of 2018, respectively. The United States' Food and Drug Administration has designated MDMA and psilocybin-assisted psychotherapies as "breakthrough therapies", and Phase-III and Phase-II clinical trials are in development for these drugs, respectively. So, it is quite probable that psychedelic-assisted psychotherapy will be approved for the treatment of some disorders in the next few years.

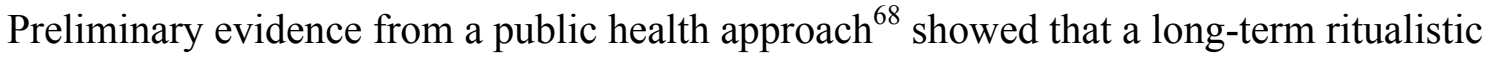
use of psychedelic drugs is associated with higher positive perception of health or with a healthy lifestyle. Additionally, $56 \%$ of the sample could diminish the use of prescription drugs due to their use of psychedelic drugs. This finding encourages us to continue researching the usefulness of psychedelics as a means to overcome at least part of the crisis in psychopharmacology. Apart from clinical approach, we should remember that there is a growing tendency towards the ritualistic and communal use of plants like ayahuasca, which can function as both a health and a self-care practice. ${ }^{69}$ These plants have been traditionally used in many cultures, and must be framed as such within the pluralistic medical systems. ${ }^{69}$ The use of these plants by shamans, traditional healers or by religious/neo-shamanic communities, alongside with biomedical research and clinical applications, must be concurrently respected and permitted.

The experiences induced by psychedelic drugs in therapeutic contexts seem to change an individual's personality structure into a healthier one, ${ }^{70}$ and they have been related to pro-environmental behavior ${ }^{71}$ and lower intimate partner violence levels. ${ }^{72}$ So, we can also expect the associated social and community benefits that psychedelic-assisted psychotherapy and traditional ceremonies offer. Most importantly, however, it is hoped that patients' satisfaction with their treatment will increase, as current patient satisfaction regarding antidepressant drug treatment remains low. ${ }^{73}$

Despite all of the advantages above mentioned, we must not forget the limitations of psychedelic-assisted psychotherapy. Current evidence is limited, so more studies are needed in order to better describe potential serious adverse events and the effectiveness of this treatment. Additionally, not all patients would be candidates for this treatment. For instance, it should not be used in patients with personal or family history of nonpsychotic mania or any psychotic illness, since psychotic episodes can appear. ${ }^{74}$ Additionally, some cases were published showing that subjects without the previous characteristics also developed psychopathological crises, but the incidence of these situations appears to be rare. ${ }^{74}$ For this reason, patients who will be administered with psychedelic drugs should be upon proper screenings and strict inclusion / exclusion criteria. $^{75}$ 


\section{Conclusion}

The paradigm shift that psychopharmacology now arguably requires could be accomplished in part by the greater introduction of psychedelic therapies. They represent an innovative approach in mental health, with the use of safer drugs that can be combined with enhanced psychotherapeutic interventions. Furthermore, in terms of use, only a few administrations are necessary, so this could mean a savings of millions of dollars for public health systems in both direct and indirect costs, ranging from the direct health costs of current treatments to the price paid by patients and families that find themselves impaired by mental illness and unable to work or cope.

Author contributions

G.O. and J.C.B. contributed equally to this work.

Funding sources

None declared. 
References

1 Green AR, Haddad PM. The British Association for Psychopharmacology: The first forty years. Cambridge, UK: British Association for Psychopharmacology, 2016.

2 Bracken $\mathrm{P}$, Thomas $\mathrm{P}$, Timimi S, et al. Psychiatry beyond the current paradigm. Br J Psychiatry 2012; 201: 430-4.

3 Kleinman A. Rebalancing academic psychiatry: why it needs to happen - and soon. Br J Psychiatry 2012; 201: 421-2.

4 Brüne M, Belsky J, Fabrega H, et al. The crisis of psychiatry - insights and prospects from evolutionary theory. World Psychiatry 2012; 11: 55-7.

5 Rubin EH, Zorumski CF. Perspective: upcoming paradigm shifts for psychiatry in clinical care, research, and education. Acad Med 2012; 87: 261-5.

6 Horrobin DF. Scientific medicine - success or failure? In: Weatherall DJ, Ledingham JGG, Warrell DA (Eds). Oxford Textbook of Medicine, 2nd edn. Oxford (UK): Oxford University Press, 1987.

7 Insel TR, Sahakian BJ. Drug research: a plan for mental illness. Nature 2012; 483: 269.

8 DePaulo JR. Bipolar disorder treatment: An evidence-based reality check. Am J Psychiatry 2006; 163: 175-6.

9 Insel TR. Disruptive insights in psychiatry: Transforming a clinical discipline. $J$ Clin Inv 2009; 119: 700-5.

10 Fibiger HC. Psychiatry, the pharmaceutical industry, and the road to better therapeutics. Schizophr Bull 2012; 38: 649-50.

11 Horrobin DF. A new category of psychotropic drugs: neuroactive lipids as exemplified by ethyl eicosapentaenoate (E-E). In Progress in Drug Research, (Jucker E, Ed.). Basel (SW): Birkhauser Verlag, 2002.

12 Hyman SE. Revolution stalled. Sci Transl Med 2012; 4.

http://dx.doi.org/10.1126/scitranslmed.3003142.

13 Rose N. Neuroscience and the future for mental health? Epidemiol Psychiatr Sci 2016; 25: 95-100.

14 Le Fanu J. Mass medicalisation is an iatrogenic catastrophe. BMJ 2018; 361. doi: 10.1136/bmj.k2794.

15 Gøtzsche PC. Does long term use of psychiatric drugs cause more harm than good? Yes. BMJ 2015; 350. doi:10.1136/bmj.h2435 
16 de Gage SB, Moride Y, Ducruet T, et al. Benzodiazepine use and risk of Alzheimer's disease: case-control study. BMJ 2014; 349. doi:10.1136/bmj.g5205.

17 Pingani L, Luciano M, Sampogna G, et al. The crisis in psychiatry: A public health perspective. Int Rev Psychiatry 2014; 26: 530-4.

18 Jakobsen JC, Katakam KK, Schou A, et al. Selective serotonin reuptake inhibitors versus placebo in patients with major depressive disorder. A systematic review with meta-analysis and Trial Sequential Analysis. BMC Psychiatry 2017; 17. doi: 10.1186/s12888-016-1173-2.

19 Khan A, Brown WA. Antidepressants versus placebo in major depression: an overview. World Psychiatry 2015; 14: 294-300.

20 Moncrieff J, Kirsch I. Efficacy of antidepressants in adults. BMJ 2005; 331: $155-7$.

21 Cipriani A, Furukawa TA, Salanti G, et al. Comparative efficacy and acceptability of 21 antidepressant drugs for the acute treatment of adults with major depressive disorder: a systematic review and network meta-analysis. Lancet 2018; 391: 1357-66.

22 Kirsch I, Deacon BJ, Huedo-Medina TB, Scoboria A, Moore TJ, Johnson BT. Initial severity and antidepressant benefits: a meta-analysis of data submitted to the Food and Drug Administration. PLoS Med 2008; 5: e45.

23 Sharma T, Guski LS, Freund N, Gøtzsche PC. Suicidality and aggression during antidepressant treatment: systematic review and meta-analyses based on clinical study reports. $B M J$ 2016; 352. doi:10.1136/bmj.i65.

24 Baldwin D, Manson C, Nowak M. Impact of antidepressant drugs on sexual function and satisfaction. CNS Drugs 2015; 29: 905-13.

25 Hamer M, Batty GD, Seldenrijk A, Kivimaki M. Antidepressant medication use and future risk of cardiovascular disease: the Scottish Health Survey. Eur Heart J 2010; 32: $437-42$.

26 Krystal JH, Davis LL, Neylan TC, Raskind M, Schnurr PP. It is time to address the crisis in the pharmacotherapy of posttraumatic stress disorder: A consensus statement of the PTSD Psychopharmacology Working Group. Biol Psych 2017; 82: e51-e59.

27 Kessler RC, Berglund P, Delmer O, Jin R, Merikangas KR, Walters EE. Lifetime prevalence and age-of-onset distributions of DSM-IV disorders in the national comorbidity survey replication. Arch Gen Psych 2005; 62: 593-602.

28 Lancaster CL, Teeters JB, Gros DF, Back SE. Posttraumatic stress disorder: Overview of evidence-based assessment and treatment. J Clin Med 2016; 5: 105.

29 Guina J, Rossetter SR, DeRhodes BJ, Nahhas RW, Welton RS. Benzodiazepines 
for PTSD: A Systematic Review and Meta-Analysis. J Psychiatr Pract 2015; 21: 281303.

30 van Gerven J, Cohen A. Vanishing clinical psychopharmacology. Br J Clin Pharmacol 2011; 72: 1-5.

31 Insel TR, Voon V, Nye JS, et al. Innovative solutions to novel drug development in mental health. Neurosci Biobehav Rev 2013; 37: 2438-44.

32 Jones R, Wilsdon J. The biomedical bubble: Why UK research and innovation needs a greater diversity of priorities, politics, places and people. London (UK): Nesta, 2018.

33 Mithoefer MC, Grob CS, Brewerton TD. Novel psychopharmacological therapies for psychiatric disorders: psilocybin and MDMA. Lancet Psych 2016; 3: 4818.

34 Sessa B. Why psychiatry needs psychedelics and psychedelics need psychiatry. J. Psychoactive Drugs 2014; 46: 57-62.

35 Sahakian BJ, Malloch G, Kennard C. A UK strategy for mental health and wellbeing. Lancet 2010; 375: 1854-5.

36 Kyzar EJ, Nichols CD, Gainetdinov RR, Nichols DE, Kalueff AV. Psychedelic drugs in biomedicine. Trends Pharmacol Sci 2018; 38: 992-1005.

37 Kubera M, Maes M, Kenis G, Kim YK, Lason W. Effects of serotonin and serotonergic agonists and antagonists on the production of tumor necrosis factor alpha and interleukin-6. Psychiatry Res 2005; 134: 251-8.

38 Yu B, Becnel J, Zerfaoui M, Rohatgi R, Boulares AH, Nichols CD. Serotonin 5-hydroxytryptamine(2A) receptor activation suppresses tumor necrosis factor-alpha-induced inflammation with extraordinary potency. J Pharmacol Exp Ther 2008; 327: 316-23.

39 Catlow BJ, Song S, Paredes DA, Kirstein CL, Sanchez-Ramos J. Effects of psilocybin on hippocampal neurogenesis and extinction of trace fear conditioning. Exp Brain Res 2013; 228: 481-91.

40 Jones KA, Srivastava DP, Allen JA, Strachan RT, Roth BL, Penzes P. Rapid modulation of spine morphology by the 5-HT2A serotonin receptor through kalirin-7 signaling. Proc Natl Acad Sci 2009; 106: 19575-80.

41 Carhart-Harris RL, Nutt DJ. Serotonin and brain function: a tale of two receptors. J psychopharmacol 2017; 31: 1091-120.

42 Ly C, Greb AC, Cameron LP, et al. Psychedelics promote structural and functional neural plasticity. Cell Reports 2018; 23: 3170-82.

43 De Gregorio D, Posa L, Ochoa-Sánchez R, et al. The hallucinogen d-lysergic diethylamide (LSD) decreases dopamine firing activity through 5-HT1A, D2 and 
TAAR1 receptors. Pharmacol Res 2016; 113: 81-91.

44 Belser AB, Agin-Liebes G, Swift TC, et al. Patient experiences of psilocybin-assisted psychotherapy: an interpretative phenomenological analysis. $J$. Humanist Psychol 2017; 57: 354-88.

45 Liechti ME, Dolder PC, Schmid Y. Alterations of consciousness and mystical-type experiences after acute LSD in humans. Psychopharmacol 2017; 234: 1499-510.

46 Eisner BG, Cohen S. Psychotherapy with lysergic acid diethylamide.

J Nerv Ment Dis 1958; 127: 528-39.

47 Majic T, Schmidt TT, Gallinat J. Peak experiences and the afterglow phenomenon: When and how do therapeutic effects of hallucinogens depend on psychedelic experiences? J Psychopharmacol 2015; 29: 241-53.

48 Osório FL, Sanches RF, Macedo LR, et al. Antidepressant effects of a single dose of ayahuasca in patients with recurrent depression: a preliminary report. Braz $J$ Psychiatr 2015; 37: 13-20.

49 Sanches RF, Osório FL, dos Santos RG, et al. Antidepressant effects of a single dose of ayahuasca in patients with recurrent depression: A SPECT study. J Clin Psychopharmacol 2016; 36: 77-81.

50 Carhart-Harris RL, Bolstridge M, Rucker J, et al. Psilocybin with psychological support for treatment-resistant depression: an open-label feasibility study. Lancet Psychiatry 2016; 3: 619-27.

51 Palhano-Fontes F, Barreto D, Onias H, et al. Rapid antidepressant effects of the psychedelic ayahuasca in treatment-resistant depression: a randomized placebo-controlled trial. Psychol Med 2018; 15: 1-9.

52 Gasser P, Holstein D, Michel Y, Doblin R, Yazar-Klosinski B, Passie T, Brenneisen R. Safety and efficacy of lysergic acid diethylamide-assisted psychotherapy for anxiety associated with life-threatening diseases. J Nerv Ment Dis 2014; 202: 51320 .

53 Griffiths RR, Johnson MW, Carducci MA, et al. Psilocybin produces substantial and sustained decreases in depression and anxiety in patients with life-threatening cancer: A randomized double-blind trial. J Psychopharmacol 2016; 30: 1181-97.

54 Grob CS, Danforth AL, Chopra GS, et al. Pilot study of psilocybin treatment for anxiety in patients with advanced-stage cancer. Arch Gen Psychiatry 2011; 68: 71-8.

55 Ross S, Bossis A, Guss J, et al. Rapid and sustained symptom reduction following psilocybin treatment for anxiety and depression in patients with life-threatening cancer: a randomized controlled trial. J Psychopharmacol 2016; 30, 1165-80. 
56 Johnson MW, Garcia-Romeu A, Cosimano MP, Griffiths RR. Pilot study of the 5-ht2aR agonist psilocybin in the treatment of tobacco addiction. $J$ Psychopharmacol 2014; 28: 983-92.

57 Danforth A, Grob CS, Struble C, et al. Reduction in social anxiety after MDMA-assisted psychotherapy with autistic adults: a randomized, double-blind, placebo-controlled pilot study. Psychopharmacol (Berl) 2018; 235: 3137-48.

58 Bouso JC, Doblin R, Farré M, Alcázar-Córcoles MA, Gómez-Jarabo G. MDMA-assisted psychotherapy using low doses in a small sample of women with chronic posttraumatic stress disorder. J Psychoactive Drugs 2008; 40: 225-36.

59 Mithoefer MC, Wagner MT, Mithoefer AT, Jerome L, Doblin R. The safety and efficacy of $\{+/-\} 3,4$-methylenedioxymethamphetamine-assisted psychotherapy in subjects with chronic, treatment-resistant posttraumatic stress disorder: the first randomized controlled pilot study. J Psychopharmacol 2011; 25: 439-52.

60 Mithoefer MC, Mithoefer AT, Feduccia AA, et al.

3,4-methylenedioxymethamphetamine (MDMA)-assisted psychotherapy for post-traumatic stress disorder in military veterans, firefighters, and police officers: a randomised, double-blind, dose-response, phase 2 clinical trial. Lancet Psychiatry 2018; 5: 486-97.

61 Oehen P, Traber R, Widmer V, Schnyder U. A randomized, controlled pilot study of MDMA ( \pm 3,4-Methylenedioxymethamphetamine)-assisted psychotherapy for treatment of resistant, chronic Post-Traumatic Stress Disorder (PTSD). $J$ Psychopharmacol 2013; 27: 40-52.

62 Ot'alora M, Grigsby J, Poulter B, et al.

3,4-Methylenedioxymethamphetamine-assisted psychotherapy for treatment of chronic posttraumatic stress disorder: A randomized phase 2 controlled trial. $J$ Psychopharmacol 2018; 32: 1295-307.

63 Bedi G. 3,4-Methylenedioxymethamphetamine as a psychiatric treatment. JAMA Psychiatry 2018; 75: 419-20.

64 dos Santos RG, Osório FL, Crippa JA, Riba J, Zuardi AW, Hallak JEC. Antidepressive, anxiolytic, and antiaddictive effects of ayahuasca, psilocybin and lysergic acid diethylamide (LSD): a systematic review of clinical trials published in the last 25 years. Ther Adv Psychopharmacol 2016; 6: 193-213.

65 dos Santos RG, Bouso JC, Hallak JEC. The antiaddictive effects of ibogaine: A systematic literature review of human studies. J Psychedelic Studies 2016; 1.

66 Johansen PO, Krebs TS. Psychedelics not linked to mental health problems or suicidal behavior: A population study. J Psychopharmacol 2015; 29: 270-9.

67 Hendricks PS, Thorne CB, Clark CB, Coombs DW, Johnson MW. Classic psychedelic use is associated with reduced psychological distress and suicidality in the United States adult population. J Psychopharmacol 2015; 29: 280-8. 
68 Ona G, Kohek M, Massaguer T, et al. Ayahuasca and public health: Health status, psychosocial wellbeing, lifestyle, and coping strategies in a large sample of ritual ayahuasca users. J Psychoactive Drugs 2019. [In press].

69 Goldsmith NM. Psychedelic healing: The promise of entheogens for psychotherapy and spiritual development. Rochester (VT): Inner Traditions \& Bear, 2010.

70 Bouso JC, dos Santos RG, Alcázar-Córcoles MÁ, Hallak JEC. Serotonergic psychedelics and personality: A systematic review of contemporary research. Neurosci Biobehav Rev 2018; 87: 118-32.

71 Forstmann M, Sagioglou C. Lifetime experience with (classic) psychedelics predicts pro-environmental behavior through an increase in nature relatedness. $J$ Psychopharmacol 2017; 31: 975-88.

72 Thiessen MS, Walsh Z, Bird BM, Lafrance A. Psychedelic use and intimate partner violence: The role of emotion regulation. J Psychopharmacol 2018; 32: 749-55.

73 Hugues S, Lacasse J, Fuller RR, Spaulding-Givens J. Adverse effects and treatment satisfaction among online users of four antidepressants. Psych Res 2017; 255: $78-86$.

74 dos Santos RG, Bouso JC, Hallak JEC. Ayahuasca, dimethyltryptamine, and psychosis: a systematic review of human studies. Ther Adv Psychopharmacol 2017; 7: 141-57.

75 Johnson MW, Richards W, Griffiths RR. Human hallucinogen research: guidelines for safety. J Psychopharmacol 2008; 22: 603-20. 